\title{
Soil erosion and sediment transport modelling using hydrological models and remote sensing techniques in Wadi Billi, Egypt
}

\author{
O. Almasalmeh ${ }^{1}$ (I) $\cdot$ Ahmed Adel Saleh ${ }^{2} \cdot$ Khaldoon A. Mourad ${ }^{3}(\mathbb{D}$
}

Received: 10 January 2021 / Accepted: 15 March 2021 / Published online: 29 March 2021

(c) The Author(s) 2021

\begin{abstract}
Modelling soil erosion and sediment transport are vital to assess the impact of the flash floods. However, limited research works have studied sediment transport, especially in Egypt. This paper employs the HEC-HMS lumped hydrological model to predict the sediment load due to the flood event of 9th March 2014 in Wadi Billi, Egypt. The Modified USLE model has been used to calculate the total upland erosion, while Laursen-Copeland has been used to simulate load streams' sediment transport potential. The Normalized Difference Vegetation Index (NDVI) has been applied over Landsat 8 image captured on 20th February 2014 using ArcMap 10.5 to determine the vegetation cover based on its spectral footprint. The resulted sedigraph showed accumulation of more than five thousand tons of sediments at the Wadi's outlet. The results are crucial to design a suitable stormwater management system to protect the downstream urban area and to use flood water for groundwater recharge.
\end{abstract}

Keywords MUSLE model $\cdot$ HEC-HMS $\cdot$ Wadi system $\cdot$ Remote sensing $\cdot$ Sedigraph $\cdot$ Egypt

\section{Introduction}

\section{Soil erosion and sediment transport}

Soil erosion and sediment transport are highly variable processes spatially and temporally, as they are mainly products of water activity (Singh et al. 2020). Therefore, at the catchment scale, they follow the spatial and temporal distribution of water flow (Şen 2008). At the local scale, the hydraulic characteristics of water flow are highly variable with short time and distance due to the complex microtopography, thus it may even lead to multiple alternating erosion and deposition processes (Morgan 2005).

Soil erosion could be motivated by different dynamic agents such as wind, rainfall, water flow, biological activities and temperature difference (Vanoni 2006). In an arid

O. Almasalmeh

O.almasalmeh@hotmail.com

1 Water Engineering, Technische Universität Berlin Campus El-Gouna, Hurghada, Egypt

2 Water Resources Research Institute, National Water Research Center, Cairo, Egypt

3 The Centre for Sustainable Visions, 22643 Lund, Sweden environment, water flow is the most significant factor that initiates erosion and transport the sediments (Horton 1945; Alhamid and Reid 2002; Şen 2008).

Channel erosion is controlled by topographic and hydraulic factors. In the youth stage, the topographic factors dominate the erosion process, where the vertical erosion is initiated, and the stream length is coinciding with the valley's length. The valley deepens increasingly and has typical $\mathrm{V}$ cross-section, and the stream's gradient is steep. As soon as the base rock is reached, the hydraulic factors start to control erosion activity, and the early mature stage of erosion starts. The lateral erosion increases the channel's width and a flood plain is established due to the lateral deposition. The stream becomes longer than the valley and its gradient is relatively flat (Mueller 1968; Şen 2008).

The erosive effect is a result of the tunnel collapsing and the interaction with surface erosion (Şen 2008). According to Morgan (2005), soil pipes work as a subsurface drainage system that transports significant amount of sediments of fine particles ranging between 4 and $8 \mu \mathrm{m}$ and dissolved solids, where large concentrations of plant nutrients and base minerals can be found.

When the bed shear stress exceeds the critical value for initiation of motion, the sediments start moving. The amount of derived sediments depends on soil properties and runoff 
characteristics (Scharffenberg 2013). Sediments deposition occurs when the flow velocity becomes less than fall velocity (Dey 2014). Many researchers developed different approaches to map sediments (El-Diasty 2020) and to calculate sediments yield (Dutta 2016) using empirical equations and models such as the GeoWEPP model (Singh et al. 2020), using the artificial neural network ANN and support vector machine (Sharma et al. 2015) and using a multiple regression model (Grauso et al. 2021). However, due to the absence of detailed quantitative studies, a threshold value to initiate soil piping erosion and sediment transport is still the main gap that prevents representing the process within soil erosion models (Bernatek-Jakiel and Poesen 2018).

\section{Flash floods within the Red Sea drainage basins}

Yearly, the Eastern Desert of Egypt is exposed to multiple storm events. Flash floods are produced and drain towards either the Red Sea or the Nile River. Unfortunately, most wadis are ungauged, and many urban settlements locate within their deltas without protection measures. Abdel-Fattah et al. (2015) estimated the damages cost for the period of 1975-2014 as 1.2 billion USD/year.

Many researchers have investigated the rainfall-runoff process in the area (Almasalmeh and Eizeldin 2019b; Abdalla et al. 2015; Abdel-Fattah et al. 2015; Elnazer et al. 2017; Hadidi 2016; Moawad et al. 2016). However, there are almost no published studies considering the soil erosion and sediment transport by flood runoff. A limited number of individual attempts exists for similar or close regions.

Elmoustafa and El-Koly (2011) estimated the amount of sediments that drain due to frequent flash floods towards the Nile River from the Eastern and Western Deserts watersheds, using the Universal Soil Loss Equation (USLE). They found out that the Eastern Wadis yield 150,000 ton/year, which is 2.3 times more than the contribution of the Western basins, and the average longitudinal deposition rate was about 360 ton/km/year.

Osman and Abu El-ella (2019) studied the sedimentological and geomorphological characteristics of the recent sediment within seven wadis drained from the Red Sea Hills towards the Nile River, throughout Qena and Luxor Governorates. They have collected 139 surface and pit samples and analyzed their grain size distribution in the laboratory using dry sieving. They found out the surface sediment ranged between gravely sand and sandy gravel, while most of the pit sediments are gravely sand. The results reflect different sedimentation cycles resulted by frequent flash flood events.

Abuabdullah and Şen (2019) calculated the bulk sediment yield rate within three wadis along the Eastern Red Sea coast, Saudi Arabia using empirical equations based on the morphological characteristics of the basins and the flood discharge. The results showed the amount of the sediment for the 100-year flood event is $0.00048,0.02165$ and 0.03064 $\mathrm{m}^{3} / \mathrm{s}$ for Al-Amud, Masturah and Yabah wadis, respectively.

\section{Methodology}

\section{Study area}

To simulate soil erosion and sediment transport, the paper takes the flood of March 9, 2014 in Wadi Billi as a case study. Wadi Billi is an arid drainage basin located in the Eastern Desert of Egypt, between the coordinates $33^{\circ} 12^{\prime}$ $33^{\prime \prime}$ to $33^{\circ} 40^{\prime} 18^{\prime \prime} \mathrm{E}$ and $26^{\circ} 57^{\prime} 56^{\prime \prime}$ to $27^{\circ} 28^{\prime} 20^{\prime \prime} \mathrm{N}$, Fig. 1 . On 9th March 2014, Wadi Billi was exposed to an intense short storm event, which produced a flash flood that passed through the canyon towards the Red Sea causing damages to the infrastructure of El-Gouna town. The precipitation volume is estimated as 35 million $\mathrm{m}^{3}$. Limited field measurement has taken place using a mobile electromagnetic flow rate measurement device (Hadidi 2016).

The wadi is poorly gauged, and it has been delineated by Digital Elevation Model (DEM) of a resolution $30 \mathrm{~m} \times 30 \mathrm{~m}$ (ASTER 2011) using Esri ArcMap 10.5. The wadi has an elongated shape with an area of $878.7 \mathrm{~km}^{2}$, and a maximum elevation of $2126 \mathrm{~m}$. It is undeveloped, except the delta, where El-Gouna town settled since the 1990s. The satellite image of Landsat 8 is showing mainly bare soil covering the different morphological features. The wadi consists of five typical morphometric features which are, from west to east: high elevated mountains, pediment plain, valleys, coastal mountains and coastal plain.

The rainfall-runoff process has been simulated using HEC-HMS 4.4, and found out $2.19 \mathrm{~mm}$ of excess precipitation (equivalent to 1.78 million $\mathrm{m}^{3}$ ) transformed into a direct runoff. Two peak values have been noticed with $54.2 \mathrm{~m}^{3} / \mathrm{s}$ at 06:00 PM and 60.3 $\mathrm{m}^{3} / \mathrm{s}$ at 08:00 PM, Fig. 2.

The HEC-HMS model simulates soil erosion and sediment transport in conjunction with the hydrological simulations. The calculated sediment load is distributed over the time-series of sediment discharge, based on the runoff hydrograph and the power function approach of Haan et al. (1994). The model recognizes the basin as a combination of individual elements (Scharffenberg 2013). The subbasin element is used to calculate the soil erosion until the streams' headwater by overland flow. The reach element is used to calculate the sediment processes by stream flow to the downstream. Figure 3 shows the detailed methodology to calculate sediment yield at the wadi outlet.

\section{Mathematical modelling}

The Modified Universal Soil Loss Equation (MUSLE) model used to calculate the total upland erosion as it considers the 


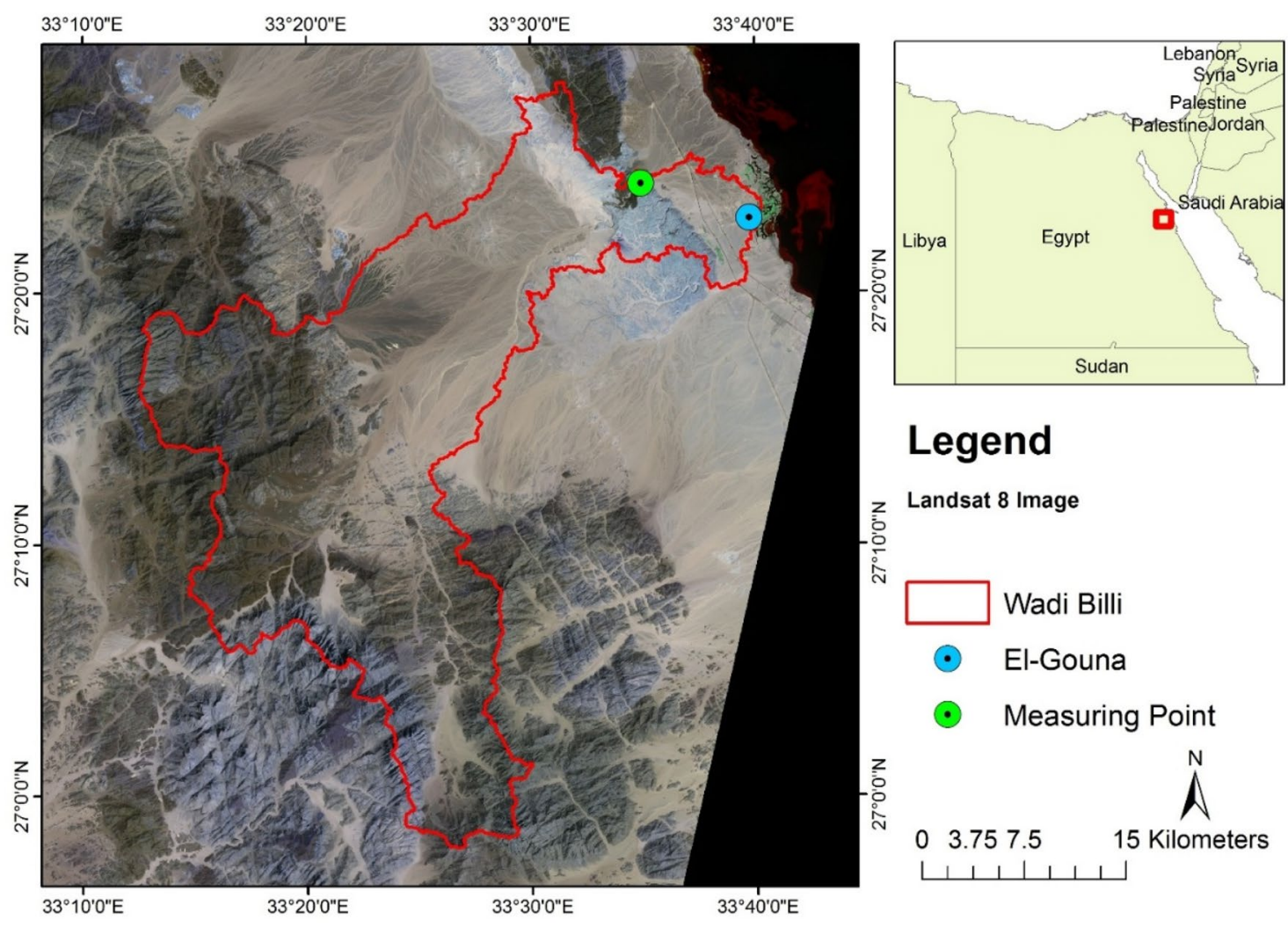

Fig. 1 Wadi Billi location

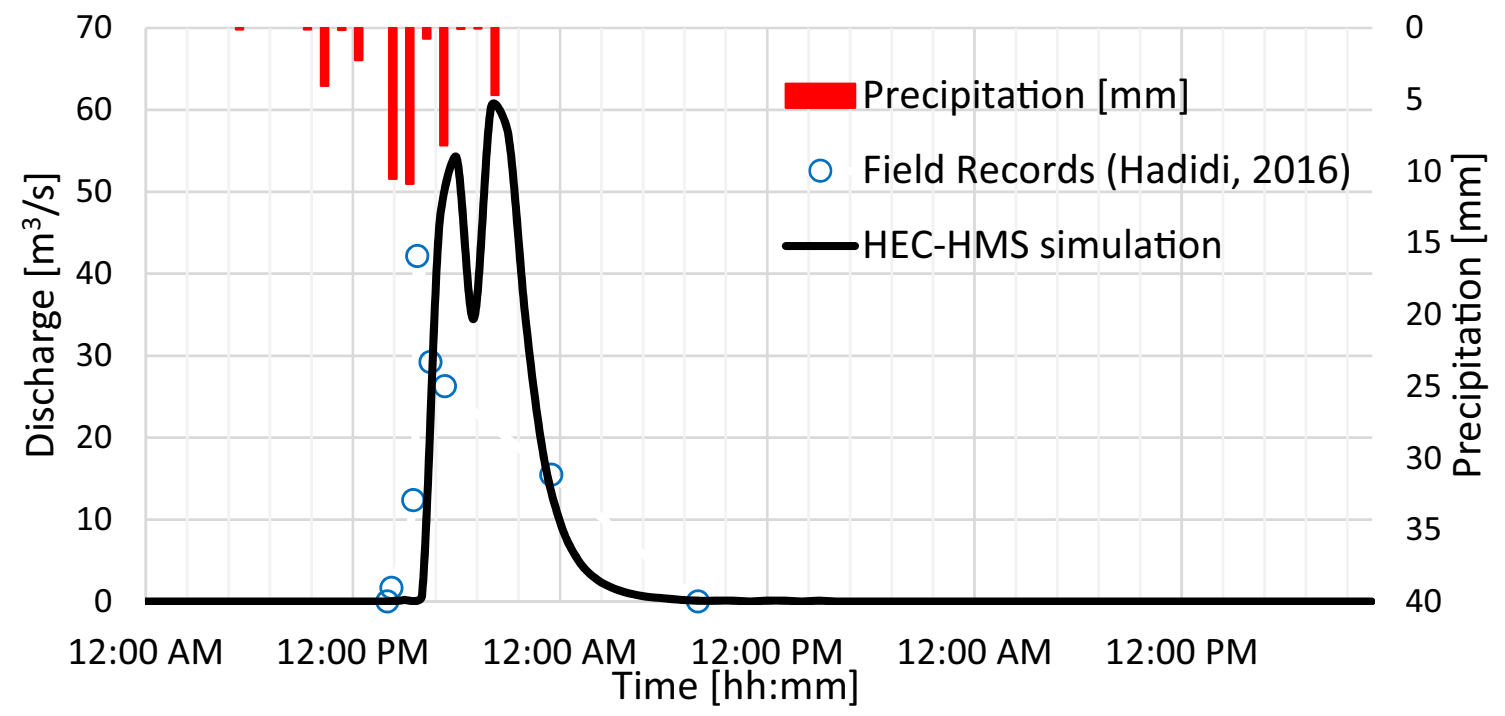

Fig. 2 Runoff hydrograph for the rainfall-runoff event of March 9, 2014

effect of rainfall factor throughout water runoff (Djoukbala et al. 2019). It is written as (Williams 1995; Pak et al. 2008):

$S=11.8\left(Q \times q_{\mathrm{p}}\right)^{0.56} \times K \times \mathrm{LS} \times C \times P$, where $S$ is the sediments yield [t], $Q$ is the runoff volume $\left[\mathrm{m}^{3}\right], q_{\mathrm{p}}$ is the peak flow rate $\left[\mathrm{m}^{3} / \mathrm{s}\right], K$ is the soil erodibility factor [-], LS is the topographic factor [-], $C$ is the cover and management factor $[-]$, and $P$ is the support practice factor $[-]$. 


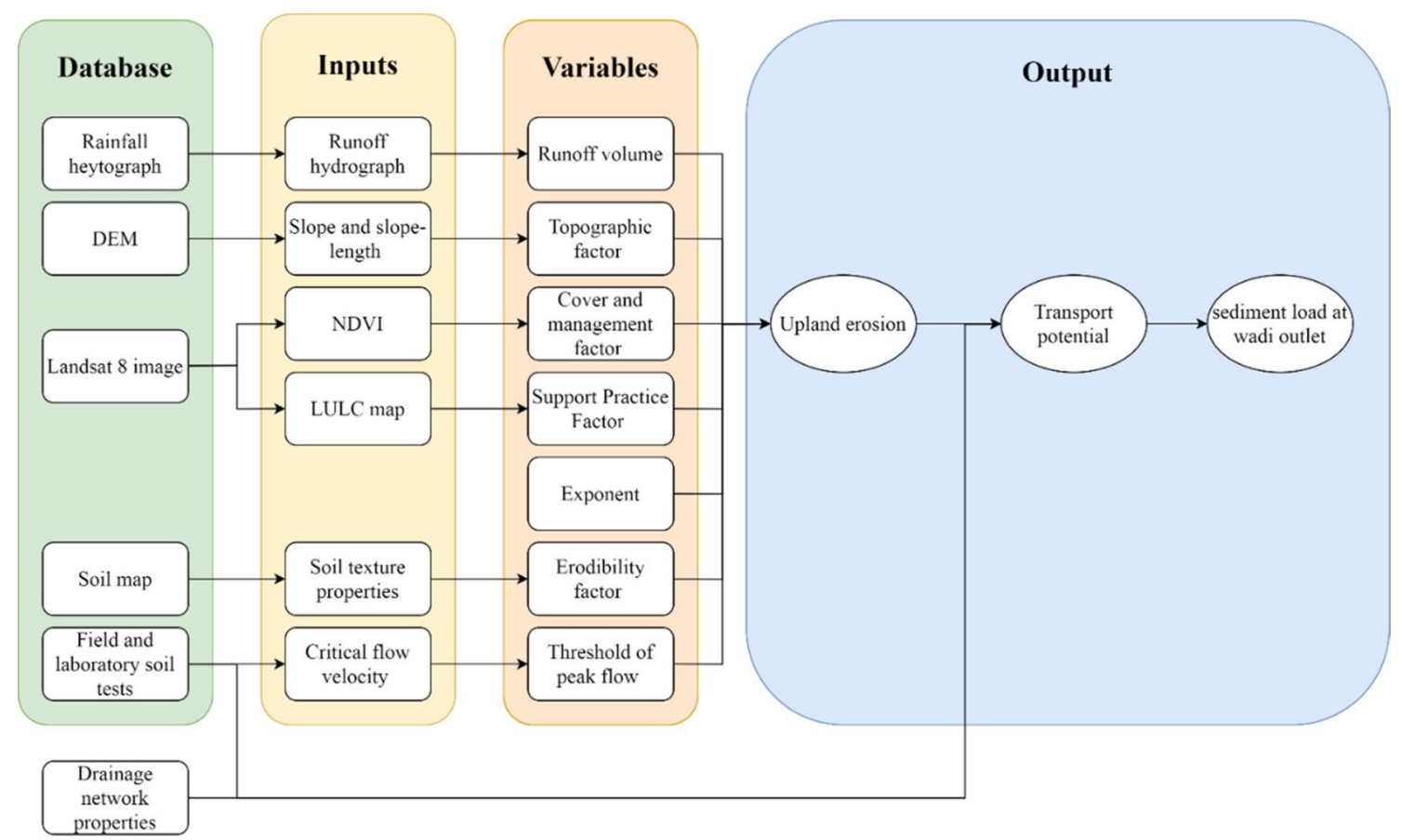

Fig. 3 The methodology of sediment yield calculation

Laursen-Copeland model is used to simulate the total load transported towards the Wadi outlet due to its suitability for wide range of grain size 0.011-29 mm (Brunner 2010):

$C_{\mathrm{m}}=0.01 \gamma \times\left(\frac{d_{\mathrm{m}}}{D}\right)^{7 / 6} \times\left(\frac{\tau_{\mathrm{o}}^{\prime}}{\tau_{\mathrm{c}}}-1\right) \times f \times\left(\frac{U_{*}}{\omega}\right)$,

where $C_{\mathrm{m}}$ is the sediment discharge concentration $\left[\mathrm{Ib} / \mathrm{ft}^{3}\right], \gamma$ is the specific weight of water $\left[\mathrm{Ib} / \mathrm{ft}^{3}\right], d_{\mathrm{m}}$ is the mean particle diameter [ft], D is the effective depth of the flow [ft], $\tau_{o}^{\prime}$ is the bed shear stress due to grain resistance $\left[\mathrm{Ib} / \mathrm{ft}^{2}\right], \tau_{\mathrm{c}}$ is the critical bed shear stress $\left[\mathrm{Ib} / \mathrm{ft}^{2}\right], f$ is the function of the ratio of the latter two variables as defined by a figure in Laursen (1958), $U_{*}$ is the shear velocity $[\mathrm{Ib} / \mathrm{s}], \omega$ is the particle fall velocity $[\mathrm{Ib} / \mathrm{s}]$.

\section{Used data}

Due to the absence of detailed soil tests, standard and average values have been chosen from the literature review where it is required. Hence, standard soil properties have been chosen for Wadi Billi, Table 1.

Soil gradation curve, Fig. 4, has been drawn based on the collected samples from Wadi Billi delta (Elsisi et al. 2018). The sieve analysis included diameters of 4-2-1.6-1.4-1.25$1.12-1-0.85-0.8-0.63-0.5-0.3-0.1-0.063$ and $0 \mathrm{~mm}$.
Table 1 Standard soil properties for Wadi Billi (Scharffenberg 2013)

\begin{tabular}{lllll}
\hline $\begin{array}{l}\text { Specific } \\
\text { gravity } \\
-\end{array}$ & $\begin{array}{l}\text { Density of } \\
\text { clay } \\
\mathrm{kg} / \mathrm{m}^{3}\end{array}$ & $\begin{array}{l}\text { Density of } \\
\text { silt }\end{array}$ & $\begin{array}{l}\text { Density of } \\
\text { sand } \\
\mathrm{kg} / \mathrm{m}^{3}\end{array}$ & $\begin{array}{l}\text { Density of } \\
\text { gravel } \\
\mathrm{kg} / \mathrm{m}^{3}\end{array}$ \\
\hline 2.65 & 481 & 1041 & 1490 & 1490 \\
\hline
\end{tabular}

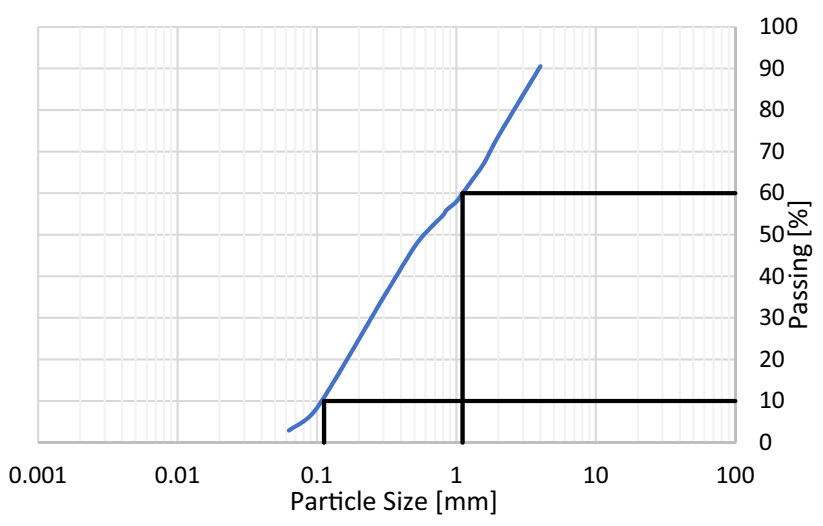

Fig. 4 Soil gradation curve at Wadi Billi delta

The soil is poorly graded and consists mainly of sand. The uniformity coefficient calculated as the following and reflects uniform graded sand soil ( $40 \%$ fine, $\sim 30 \%$ medium, and $30 \%$ coarse): 
$U=\frac{d_{60}}{d_{10}}=\frac{1.11}{0.11}=9.85$

The erodibility factor is calculated after Williams (1995) equation as cited by Benavidez et al. (2018):

$K_{\mathrm{USLE}}=f_{\mathrm{c} \mathrm{sand}} \times f_{\mathrm{cl}-\mathrm{si}} \times f_{\text {orgc }} \times f_{\text {hi sand }}$

$f_{\text {c sand }}=0.2+0.3 \times \exp \left[-0.256 \times m_{\mathrm{s}} \times\left(1-\frac{m_{\text {silt }}}{100}\right)\right]$

$f_{\text {cl-si }}=\left(\frac{m_{\text {silt }}}{m_{\mathrm{c}}+m_{\text {silt }}}\right)^{0.3}$

$f_{\text {orgc }}=1-\frac{0.0256 \times \operatorname{orgc}}{\operatorname{org} C+\exp (3.72-2.95 \times \operatorname{org} C)}$

$$
f_{\text {hi sand }}=1-\frac{0.7 \times\left(1-\frac{m_{\mathrm{s}}}{100}\right)}{\left(1-\frac{m_{\mathrm{s}}}{100}\right)+\exp \left[-5.51+22.9 \times\left(1-\frac{m_{\mathrm{s}}}{100}\right)\right]}
$$

where $m_{\mathrm{s}}$ is the percent of sand content $(0.05-2 \mathrm{~mm}$ diameter particles) [\%], $m_{\text {silt }}$ is the percent of silt content (0.002-0.05 mm diameter particles) [\%], $m_{\mathrm{c}}$ is the percent of clay content $\left(<0.002 \mathrm{~mm}\right.$ diameter particles) [\%], ${ }_{\mathrm{org}} C$ is the percent of organic carbon content [\%].

Mainly three types of soil are determined, Fig. 5. Coarse sand distributed over the coastal and pediment plains, medium loam distributed over wadis' bed and medium clay loam distributed as a thin layer over the western mountainous area and coastal ridge. Soil fractions have been calculated for the topsoil cover based on standard values from HWSD, Table 2.
Fig. 5 Soil map of Wadi Billi (FAO/IIASA/ISRIC/ISSCAS/ JRC 2012)

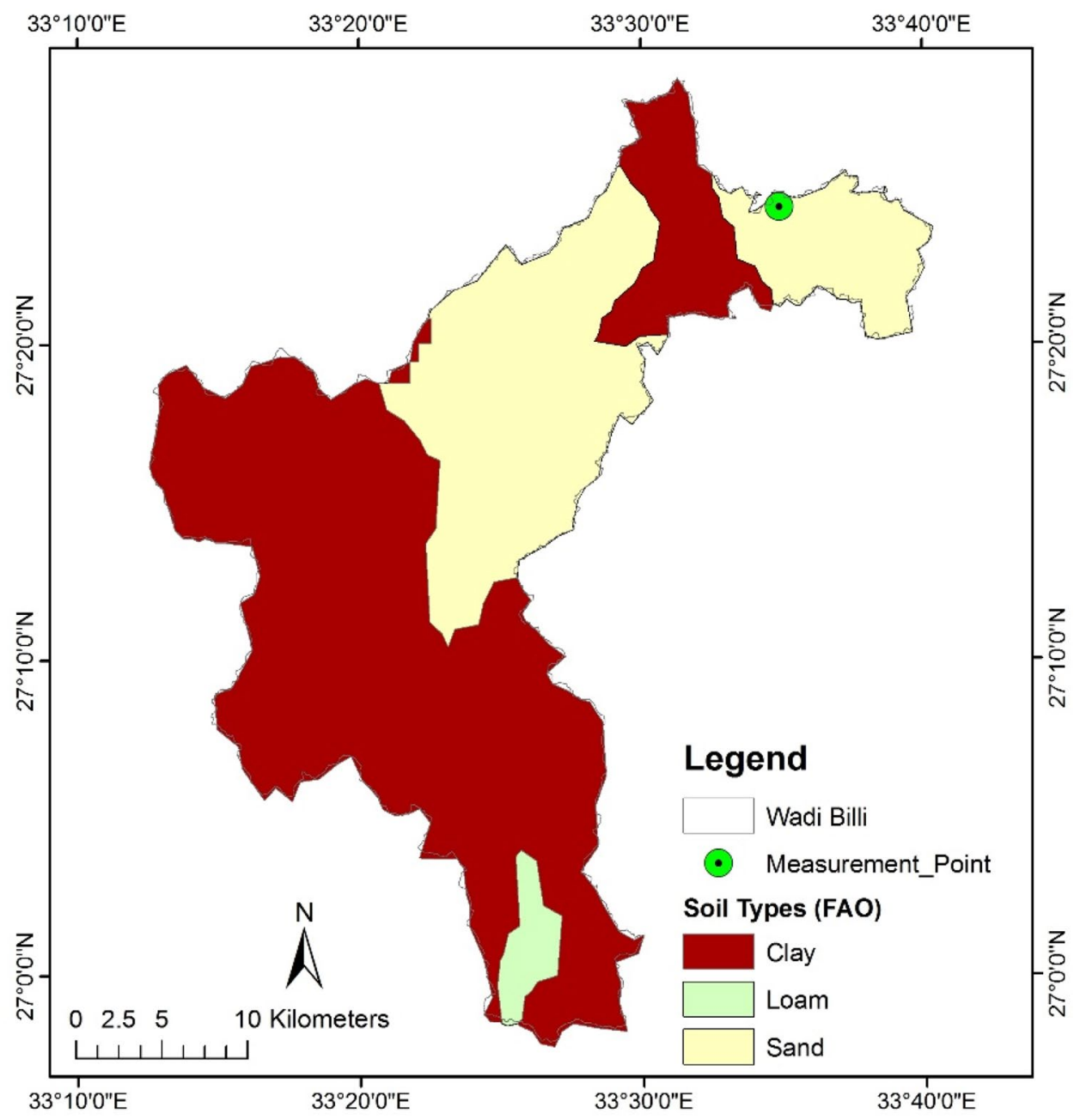


Table 2 Erodibility factor for the Wadi Billi soil map after (FAO/IIASA/ISRIC/ISSCAS/JRC 2012)

\begin{tabular}{|c|c|c|c|c|c|c|c|c|c|c|c|}
\hline MU global & $\begin{array}{l}\text { Topsoil texture } \\
\text { classification }\end{array}$ & Topsoil gravel & Topsoil sand & Topsoil silt & Topsoil clay & $\begin{array}{l}\text { Topsoil } \\
\text { organic } \\
\text { carbon }\end{array}$ & $f_{\text {csand }}$ & $f_{\text {cl-si }}$ & $f_{\text {orgc }}$ & $f_{\text {hi sand }}$ & $K_{\text {ULSE }}$ \\
\hline- & - & $\%$ & $\%$ & $\%$ & $\%$ & $\%$ & - & - & - & - & - \\
\hline 16,369 & Sand & 1 & 89 & 6 & 5 & 0.23 & 0.2 & 0.99 & 1 & 1 & 0.198 \\
\hline 16,442 & Clay loam & 32 & 43 & 29 & 28 & 0.39 & 0.2 & 1.00 & 1 & 1 & 0.199 \\
\hline 16,418 & Loam & 1 & 44 & 33 & 23 & 0.73 & 0.2 & 0.99 & 1 & 1 & 0.198 \\
\hline
\end{tabular}

The topographic factor considers the effect of slope and slope-length through flow accumulation, cell size and slope. It has been calculated after Moore and Burch (1985) equation as cited by Benavidez et al. (2018):

$\mathrm{LS}=(m+1) \times\left(\frac{U}{L_{\mathrm{o}}}\right)^{m} \times\left(0.01745 \times \frac{\sin \beta}{S_{\mathrm{o}}}\right)^{n}$,

$U=$ flow accumulation $\times$ cell size

where $m$ (sheet) and $n$ (rill) factors depend on the domina type of erosion [ $m=0.4$ and $n=1.3$ ], $U$ is the upslope contributing area per unit width as a proxy for discharge $\left[\mathrm{m}^{2} / \mathrm{m}\right]$,

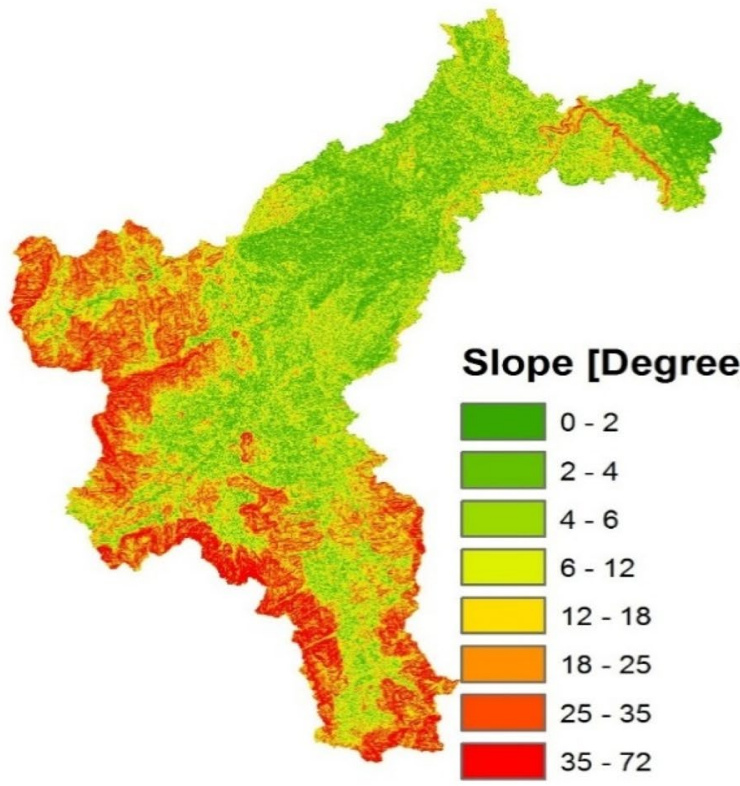

Fig. 6 Slope (left), and elevation (right) of Wadi Billi
$L_{\mathrm{o}}$ is the length of the unit plot $\left[L_{\mathrm{o}}=22.1\right], \beta$ is the slope anree], $S_{\mathrm{o}}$ is the slope of a unit plot $\left[S_{\mathrm{o}}=0.09\right]$.

\section{Results and discussion}

\section{Generating the slope map and the drainage network}

The slope map of Wadi Billi has been generated using the Surface Analysis Tool in Esri ArcMap 10.5 (Fig. 6-left). The wide variations between slope values is due to the variation of topography and the distribution of the different 


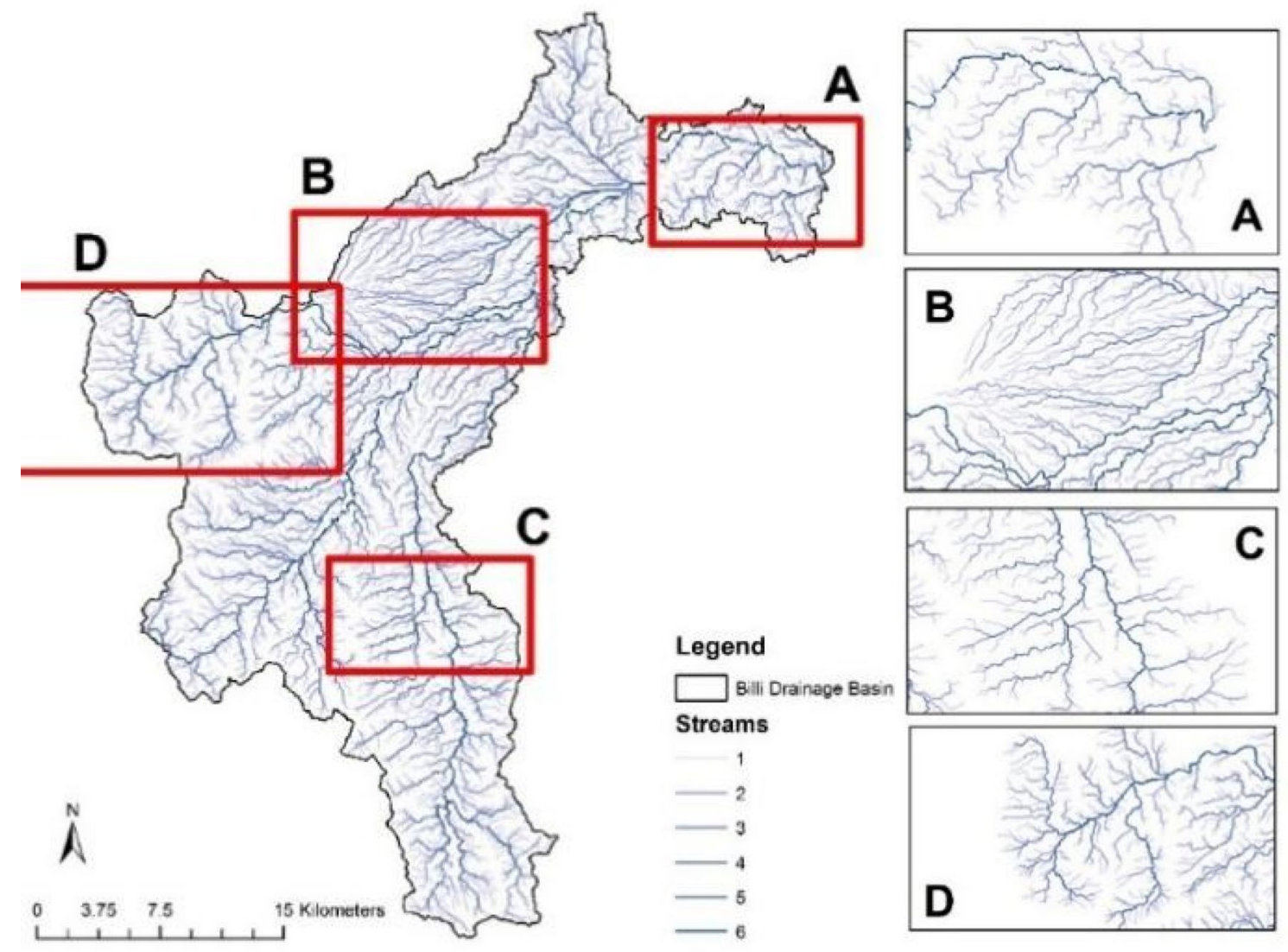

Fig. 7 Drainage network of Wadi Billi

morphometric types (Fig. 6-right): western mountains area, central desert plateau, mountain ridges, Billi canyon, and the coastal plain. The average gradient of the coastal plain surface is $4.2 \mathrm{~m} / \mathrm{km}$ in smooth distribution. While it is doubled for the flat plateau of Abu Sha' ar with $8.5 \mathrm{~m} / \mathrm{km}$. The average gradient is reduced for Billi canyon before penetrating ridge of Esh Al-Mellaha mountain to $3 \mathrm{~m} / \mathrm{km}$, then it is increased to $11.9 \mathrm{~m} / \mathrm{km}$ for parts that penetrate the ridge mountain, while the wadi wall sides have steep slope over $35^{\circ}$. The moderate slope distributing on the ridge of Esh Al-Mellaha, where it is permeated by heights with slopes up to $15^{\circ}$, and not exceed $6^{\circ}$ in the north part. The steepest slope distributed on mountainous areas is in the western part of the basin which is above $35^{\circ}$ and exceeds $72^{\circ}$ for parts of Abu Dukhan mountain.

The drainage network has mainstream of 6 th order according to Strahler classification system (Fig. 7). The network consists of 3,382 streams with a total length of $2383.2 \mathrm{~km}$. The mean bifurcation ratio is 4.97 referring to mountainous and well-dissected landform. The high drainage density value of $2.71 \mathrm{~km} / \mathrm{km}^{2}$ referring to old stage landform includes gullied slopes and low permeable surface. Different drainage patterns can be noticed. The dendritic pattern (A) is the most common and refers generally to a fairly homogeneous rock without controlling the underlying geologic structure as in the western part of Wadi Bill, while it refers to a homogeneous soil cover as in most parts of Wadi Billi. The parallel type (B) exists within Abu Sha' ar Plateau and explains the highest value of drainage density. The trellis pattern $(\mathrm{C})$ emerged where the tributaries meet with the parent stream at almost $90^{\circ}$ angles and indicates a folded topography as the tributaries developed in valleys that resulted from synclines. The rectangular pattern (D) 


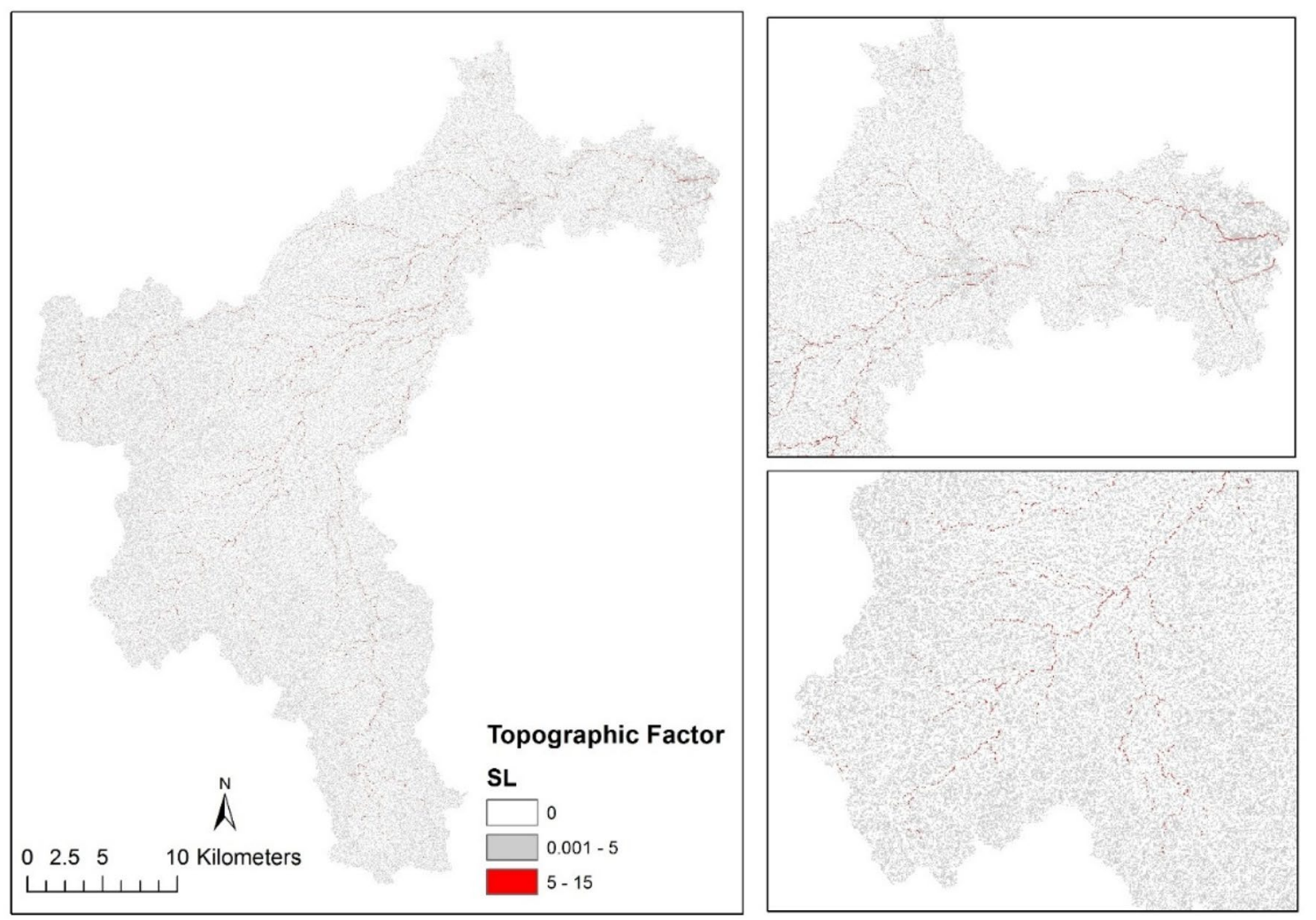

Fig. 8 Spatial distribution of topographic factor over Wadi Billi

refers to a fault topography and indicates rocks that have approximately uniform resistance to erosion.

\section{Spatial distribution}

Figure 8 shows the spatial distribution of the topographic factor over Wadi Billi. Higher values are distributed over the drainage network, relatively moderate values spread over mountainous areas, while low values cover almost the whole wadi area. The mean value for the topographic factor is 0.36 .

\section{Land use land cover}

The Normalized Difference Vegetation Index (NDVI) has been applied over Landsat 8 image captured on 20th February 2014 using ArcMap 10.5 to determine the vegetation cover based on its spectral footprint. Figure 9 shows only two main locations within the wadi delta record dense vegetation with an area of $818,526 \mathrm{~m}^{2}$. The satellite sensors did not record any vegetation within Wadi Billi, which refers to a very sparse and insignificant amount of vegetation. Thus, the cover factor has been determined from literature after Morgan (2005), and the highest erosion is recommended: $C=1$.

The practice factor considers the effects of soil conservation practice of agricultural lands (contouring, terracing, or strip cropping) over runoff pattern and thus over soil erosion rate. A supervised classification analysis has been applied over the Landsat 8 image using ArcMap 10.5 to determine the land use and land cover. Figure 9 shows that Wadi Billi is undeveloped, except in the delta, where roads network and El-Gouna town are located in the coastal plain. The wadi consists of unconsolidated (sand and gravel) and consolidated (thin layer of clay over base rocks) bare areas representing $58 \%$ and $41 \%$ of the total area, respectively. Therefore, a maximum value of practice factor $P=1$ as recommended by Benavidez et al. (2018). 
Fig. 9 Land Use Land Cover (LULC) map for Wadi Billi
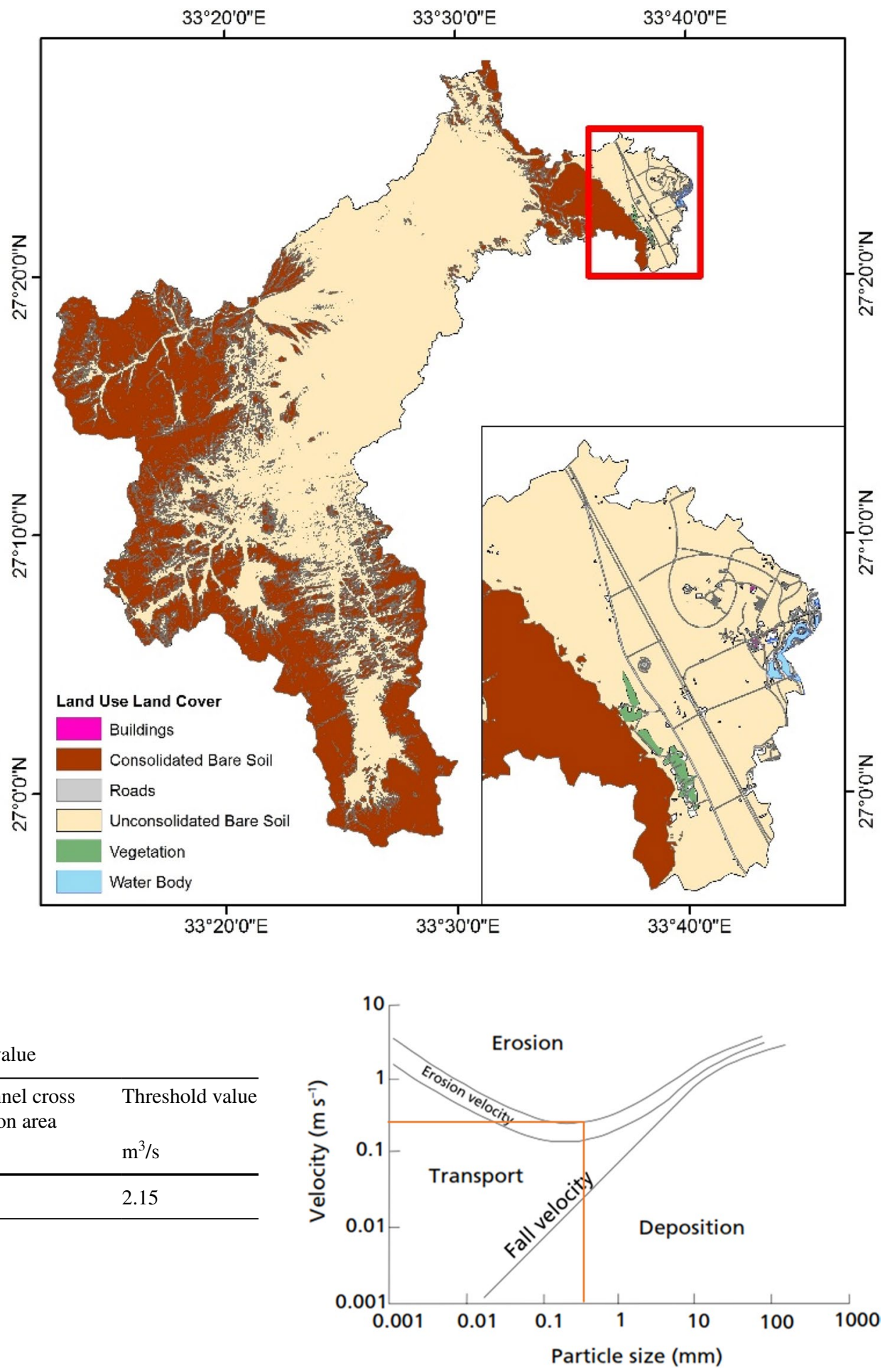

\section{The threshold value}

The threshold value denotes a critical runoff peak value that causes soil erosion, Table 3. It has been calculated as a
Table 3 Calculations of the threshold value

\begin{tabular}{llll}
\hline $\begin{array}{l}\text { Median parti- } \\
\text { cle size }\end{array}$ & $\begin{array}{l}\text { Critical Shear } \\
\text { velocity } \\
\mathrm{m} / \mathrm{s}\end{array}$ & $\begin{array}{l}\text { Channel cross } \\
\text { section area } \\
\mathrm{m}^{2}\end{array}$ & $\begin{array}{l}\text { Threshold value } \\
\mathrm{m}^{3} / \mathrm{s}\end{array}$ \\
\hline 0.6 & 0.3 & 7.16 & 2.15 \\
\hline
\end{tabular}

Fig. 10 Hjulström (1935) diagram shows the relationship between flow critical velocity and particle size for soil detachment, transportation and settling (Morgan 2005) 
Table 4 Input parameters for Modified USLE

\begin{tabular}{|c|c|c|c|c|c|}
\hline $\begin{array}{l}\text { Erod- } \\
\text { ibility } \\
\text { factor }\end{array}$ & $\begin{array}{l}\text { Topo- } \\
\text { graphic } \\
\text { Factor }\end{array}$ & Cover factor & $\begin{array}{l}\text { Prac- } \\
\text { tice } \\
\text { factor }\end{array}$ & Threshold & Exponent \\
\hline- & - & - & - & $\mathrm{m}^{3} / \mathrm{s}$ & - \\
\hline 0.2 & 0.36 & 1 & 1 & 2.15 & 1 \\
\hline
\end{tabular}

function of critical flow velocity that has been determined based on soil median grain size based on Hjulström (1935) diagram, Fig. 10.

Finally, the exponent controls the distribution of the sediments load over sedigraph time series. A linear value has been chosen: Exponent $=1$.

The input parameters for the Modified USLE are presented in Table 4.

\section{Sediment transport simulation}

The resulted sedigraph (Fig. 11) coincides with the runoff hydrograph in terms of shape and time to peaks. The sediment transport starts at 05:00 PM and extends to 05:00 AM on next day. The total transported sediment load is 5523.1 $t$ for the whole event. Two peaks have been predicted at the wadi outlet, which attain 1015 and 1386 ton at 06:00 and 09:00 PM, respectively.

\section{Sensitivity analysis}

All factors of the Modified USLE model, the threshold of soil erosion and the exponent have been considered. The range of the used values is matching with the possible range of mistakes. The aim is to examine the effect of each factor on the predicted sedigraph and determines the most sensitive ones.

For the factors derived using remote sensing and geoprocessing techniques, the applied range is the actual measurement $\pm 10 \%$, because of the measurement accuracy. While for the factors that require field measurements, the used range is the actual measurement $\pm 25 \%$.

The results show that all factors are equally sensitive and significantly influence the predicted sedigraph in terms of sediment load and peak values, Fig. 12. No changes have been noticed in terms of time to peak or sedigraph shape. The threshold of soil erosion almost did not influence the resulted sedigraph. This can be attributed to the nature of flash flood runoff, where the runoff hydrograph is characterized by a rapid rise and fall limbs. Therefore, the difference of discharge between each two subsequent simulation steps is larger than the applied

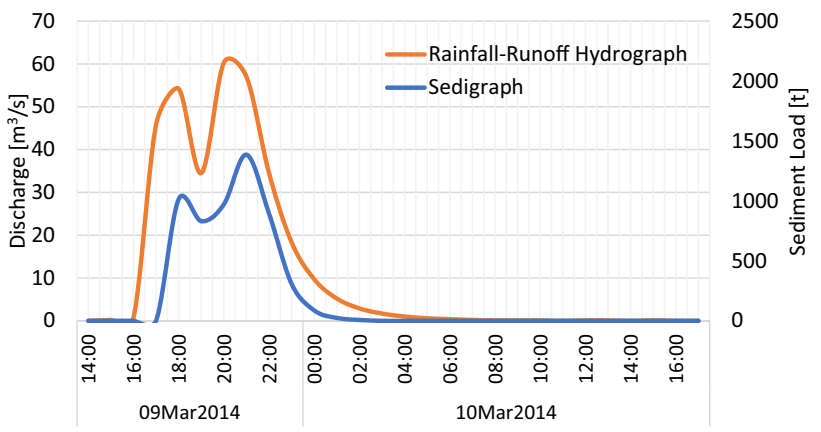

Fig. 11 Sedigraph of Wadi Billi for the flood event of 9th March 2014

range of threshold values. The exponent controls the distribution of the same sediment load over the time series. Thus, it significantly influences sedigraph shape and the peak values.

Therefore, it is recommended to calibrate all factors and the exponent using field observation to conclude the exact sedigraph. Due to the accuracy of remote sensing and GIS techniques, the topographic, cover and practice management factors are realistic to a large extend. While, special consideration is required for the erodibility factor, as it is derived based on limited soil tests.

\section{Conclusion}

Repetitive flash floods occur in the Eastern Desert of Egypt, which carry large quantities of water and sediments towards the urban areas in the delta causing severe damages. Limited rainfall-runoff studies considering sediment transport and yield are taken place. Therefore, this research aims to model the soil erosion and sediment transport processes resulted from the flash flood event of 9th March 2014 within Wadi Billi, Egypt. The Modified USLE model has been used to calculate the total upland erosion, while Laursen-Copeland has been used to simulate load streams' sediment transport potential. The results showed that more than 5500 ton of sediments reached the wadi outlet and all modelling parameters are sensitive. However, special consideration is required for the erodibility factor, as it is derived only based on field tests. Moreover, the sediment load would significantly influence the performance of any suggested stormwater management system that would store floodwater behind surface dams or recharge it into local shallow aquifers. Therefore, it is recommended to design a suitable sediment trap system in the upstream to keep the designed performance at its optimum. 

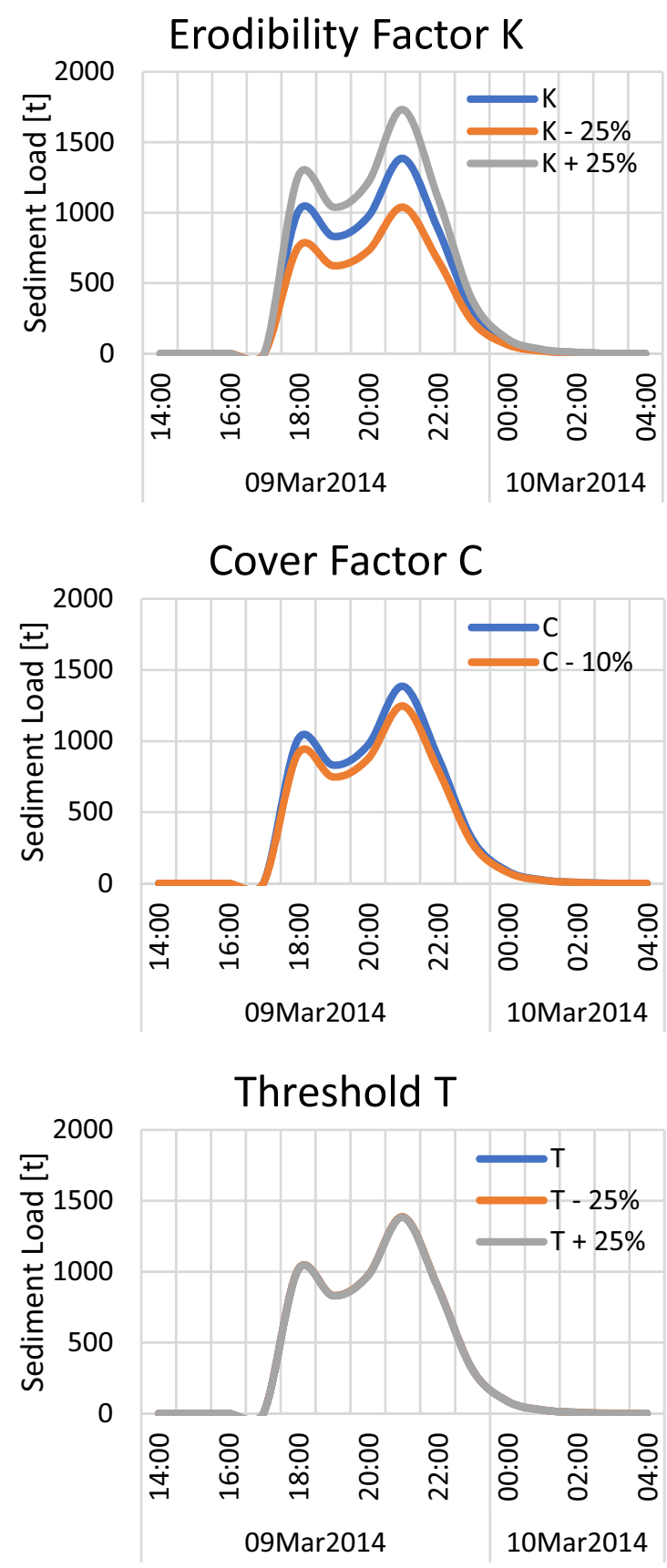

Fig. 12 Sensitivity analysis for sediment transport modelling factors

Acknowledgements The first author is acknowledging Prof. Reinhard Hinkelmann and Mrs. Franziska Tügel from Chair of Water Resources Management and Modeling of Hydrosystems, Technische Universität Berlin, for the fruitful discussions, comments and guiding.

Funding Open Access funding enabled and organized by Projekt DEAL.. Not applicable.

Availability of data and material The data that support the findings of this study are available from the corresponding author upon reasonable request.
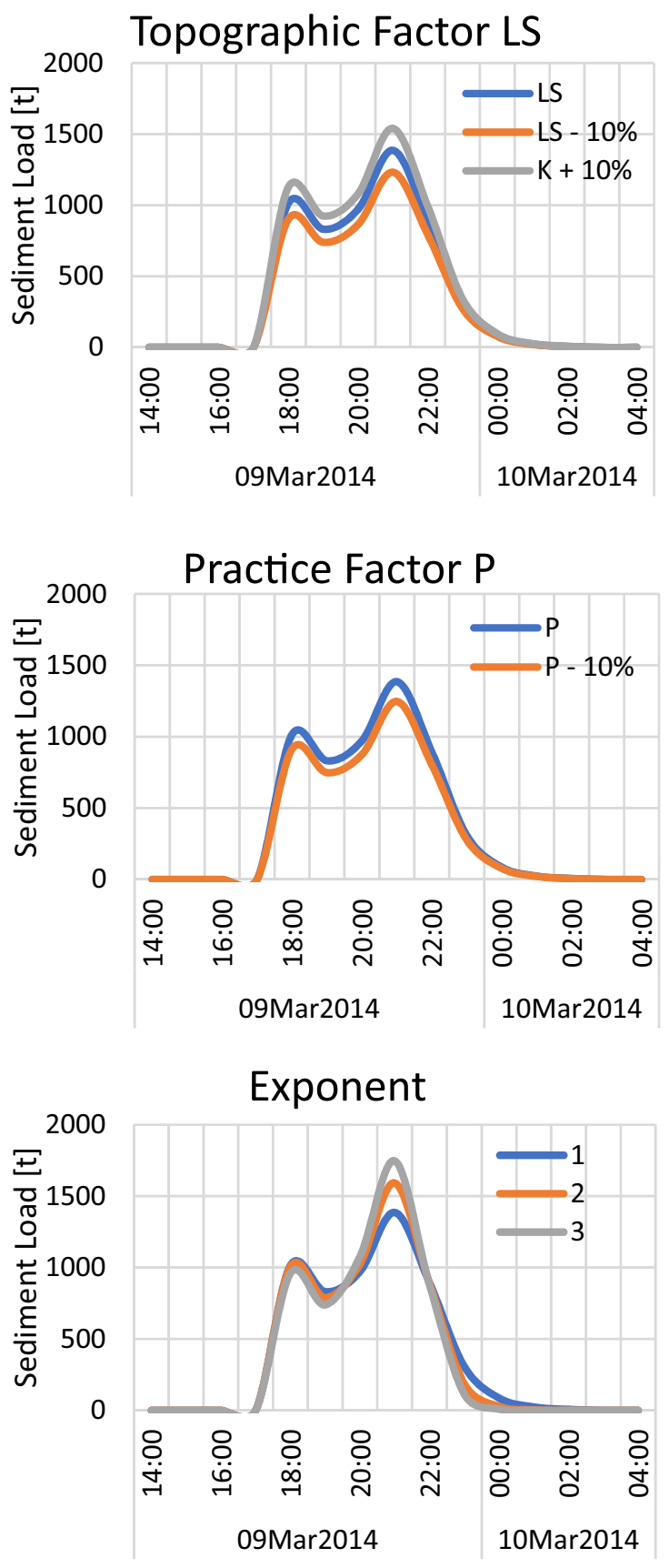

Software availability The HEC-HMS is available for free from: https:// www.hec.usace.army.mil/software/hec-hms/.

\section{Declarations}

Conflict of interest The authors declare no conflict of interest.

Open Access This article is licensed under a Creative Commons Attribution 4.0 International License, which permits use, sharing, adaptation, distribution and reproduction in any medium or format, as long as you give appropriate credit to the original author(s) and the source, 
provide a link to the Creative Commons licence, and indicate if changes were made. The images or other third party material in this article are included in the article's Creative Commons licence, unless indicated otherwise in a credit line to the material. If material is not included in the article's Creative Commons licence and your intended use is not permitted by statutory regulation or exceeds the permitted use, you will need to obtain permission directly from the copyright holder. To view a copy of this licence, visit http://creativecommons.org/licenses/by/4.0/.

\section{References}

Abdalla F, Shamy IE, Bamousa AO, Mansour A, Mohamed A, Tahoon M (2015) Flash Floods and groundwater recharge potentials in arid land alluvial basins, southern red sea coast. Egypt Int J Geosci 5(9):971-982

Abdel-Fattah M, Kantoshu S, Sumi T (2015) Integrated management of flash flood in Wadi system of Egypt: disaster prevention and water harvesting. Disaster Prevent Res Inst Annu 58(B):485-496

Abuabdullah M, Şen Z (2019) Sediment yield calculation along the red sea coastal drainage basins. In: Rasul NM, Stewart IC (eds) Geological setting, palaeoenvironment and archaeology of the Red Sea. Springer, Cham, pp 519-531. https://doi.org/10.1007/ 978-3-319-99408-6_23

Alhamid AA, Reid I (2002) Sediment and the vulnerability of water resources. In: Wheater $\mathrm{H}, \mathrm{Al}-W e s h a h$ RA (eds) Hydrology of Wadi systems. UNESCO, International Hydrological Programme V, Paris, pp 37-56

Almasalmeh O, Eizeldin M (2019b) Flash flood modelling of ungauged watershed based on geomorphology and kinematic wave: case study of Billi Drainage Basin, Egypt. In: Ismailia: Twenty-Second International Water Technology Conference (IWTC-XXII)

ASTER A S (2011) Digital Elevation Model. METI \& NASA

Benavidez R, Jackson B, Maxwell D, Norton K (2018) A review of the (Revised) Universal Soil Loss Equation ((R)USLE): with a view to increasing its global applicability and improving soil loss estimates. Hydrol Earth Syst Sci 22(11):6059-6086. https://doi. org/10.5194/hess-22-6059-2018

Bernatek-Jakiel A, Poesen J (2018) Subsurface erosion by soil piping: significance and research needs. Earth. https://doi.org/10.1016/j. earscirev.2018.08.006

Brunner G W (2010) HEC-RAS, river analysis system hydraulic reference manual. In: Davis: US Aemy Corps of Engineers, Hydrologic Engineering Center

Dey S (2014) Fluvial hydrodynamics: hydrodynamic and sediment transport phenomena. Springer, Berlin

Djoukbala O, Hasbaia M, Benselama O, Mazour M (2019) Comparison of the erosion prediction models from USLE, MUSLE and RUSLE in a Mediterranean watershed, case of Wadi Gazouana (N-W of Algeria). Model Earth Syst Environ 5:725-743. https:// doi.org/10.1007/s40808-018-0562-6

Dutta S (2016) Soil erosion, sediment yield and sedimentation of reservoir: a review. Model Earth Syst Environ 2:123. https://doi.org/ 10.1007/s40808-016-0182-y

El-Diasty M (2020) Mapping seabed sediments for Sharm Obhur using multibeam echosounder backscatter data. Model Earth Syst Environ 6:163-171. https://doi.org/10.1007/s40808-019-00668-x

Elmoustafa AM, El-Koly KS (2011) Assessment of flash floods flowing to nile main stream between Aswan and Assiut. Al Azhar J 20011:5
Elnazer AA, Salman SA, Asmoay AS (2017) Flash flood hazard affected Ras Gharib City, Red Sea, Egypt: a proposed flash flood channel. Nat Hazards 89(6):1389-1400

Elsisi M, George M, Hubeishi Y (2018) Flash Flood Management of Wadi Bili. In: El-Gouna: Technical University of Berlin, Campus El-Gouna, Water Engineering Department

FAO/IIASA/ISRIC/ISSCAS/JRC (2012) Harmonized world soil database (version 1.2). In: Rome, Italy and IIASA, Laxenburg, Austria: FAO

Grauso S, Pasanisi F, Tebano C et al (2021) A multiple regression model to estimate the suspended sediment yield in Italian Apennine rivers by means of geomorphometric parameters. Model Earth Syst Environ 7:363-371

Hadidi A (2016) Wadi Bili catchment in the eastern desert: flash floods, geological model and hydrogeology. In: Dissertation: Technische Universität Berlin.

Hjulström F (1935) Studies of morphological activity of rivers as illustrated by the River Fyris. Bull Geol Inst University Uppsala 25:221-527

Horton RE (1945) Erosional development of streams and their drainage basins; hydrophysical approach to quantitative morphology. Bull Geol Soc Am 56(3):275-370

Laursen EM (1958) The total sediment load of streams. J Hydraulics Division ASCE 84(1):1530-1-1530-36

Moawad MB, Aziz AO, Mamtimin B (2016) Flash floods in the Sahara: a case study for the 28 January 2013 flood in Qena, Egypt. Geomatics Natural Hazards Risk 7(1):215-236

Morgan RP (2005) Soil erosion and conservation, 3rd edn. Blackwell Science Ltd, London

Mueller JE (1968) An introduction to the hydraulic and topographic sinuosity indexes. Ann Assoc Am Geogr 58(2):371-385

OsmanAbu el-ella MRKA (2019) Sedimentological and environmental studies of the recent sediments of Some wadis in Qena and Luxor Governorates, Upper Egypt. J Appl Geol Geophys 7(6):13-28

Pak J, Fleming M, Scharffenberg W, Ely P (2008) Soil Erosion and sediment yield modeling with the hydrologic modeling system (HEC-HMS). In: Ahupua'a: World Environmental and Water Resources Congress. https://doi.org/10.1061/40976(316)362

Scharffenberg WA (2013) Hydrologic modeling system HEC-HMS: user's manual. In: Davis: hydrologic engineering center, US Army Corps of Engineers

Şen Z (2008) Wadi hydrology. Taylor \& Francis Group, LLC, Berlin

Sharma N, Zakaullah M, Tiwari H et al (2015) Runoff and sediment yield modeling using ANN and support vector machines: a case study from Nepal watershed. Model Earth Syst Environ 1:23. https://doi.org/10.1007/s40808-015-0027-0

Singh A, Kumar S, Naithani S (2020) Modelling runoff and sediment yield using GeoWEPP: a study in a watershed of lesser Himalayan landscape. India Model Earth Syst Environ. https://doi.org/ 10.1007/s40808-020-00964-x

Vanoni VA (2006) Sedimentation engineering. American Society of Civil Engineers, Reston

Williams JR (1995) Chapter 25: the EPIC model. In: Singh VP (ed) Computer models of watershed hydrology. Water Resources Publications, pp 909-1000

Publisher's Note Springer Nature remains neutral with regard to jurisdictional claims in published maps and institutional affiliations. 